\title{
ANALISIS PENGARUH FAKTOR HARGA, PENDAPATAN, KUALITAS DAN ATRIBUT PRODUK ISLAM TERHADAP PURCHASE INTENTION DI KEDAI KOPI BYCOFFEE SURABAYA ${ }^{1}$
}

\section{Reyhan Devtyan Muhamad}

Departemen Ekonomi Syariah-Fakultas Ekonomi dan Bisnis-Universitas Airlangga Email: reyhan.devtyan.muhamad-2015@feb.unair.ac.id

\section{Eko Fajar Cahyono}

Departemen Ekonomi Syariah-Fakultas Ekonomi dan Bisnis-Universitas Airlangga Email: ekofajarc@feb.unair.ac.id

\begin{abstract}
:
This study aims to analyze the influence of prices, income, quality and attributes of the Islamic religion on consumer purchasing decisions in the ByCoffee branch Coffee shop in the Surabaya city. In this study the authors used a quantitative method by collecting primary data from 120 respondents. The analytical method used is SEM PLS. The results showed that all factors had a significant influence on purchasing decisions except price factors. Significantly influential factors are Islamic quality and attribute factors while income factors have a less strong influence.
\end{abstract}

Keywords: price, revenue, quality, Islamic attributes, purchasing decisions.

\section{PENDAHULUAN}

Dewasa ini kopi kerap kali menjadi topik perbincangan di masyarakat, karena saat ini kopi merupakan salah satu jenis minuman yang paling digemari di seluruh dunia, tak terkecuali di Indonesia. Minum kopi telah menjadi tren gaya hidup masyarakat kosmopolitan di kota-kota besar. kebiasaan ngopi di coffee shop sebenarnya sudah lama menjadi kebiasaan di negara-negara Barat. Dengan adanya pengaruh globalisasi, tren ini pun akhirnya ikut merambah ke masyarakat negeri kita

Menurut data Biro Pusat Statistik (BPS) tahun 2014, kopi merupakan salah satu komoditi ekspor utama Indonesia bahkan menempati peringkat keempat terbesar di dunia. Dari total produksi kopi, sekitar $67 \%$ diekspor ke luar negeri sedangkan sisanya yaitu $33 \%$ dialokasikan untuk memenuhi kebutuhan dalam negeri. Tingkat konsumsi dalam negeri diperkirakan oleh para pengusaha kopi telah mencapai 800gram/kapita/tahun.

Indonesia merupakan salah satu negara muslim dengan tingkat konsumsi produk halal terbesar dunia. Konsumsi akan produk halal ini sebesar $7 \%$ berasal dari impor. Tren ngopi di coffee shop sudah menjadi budaya masyarakat di kota-kota besar, tak terkecuali di kota Surabaya. Kota Surabaya adalah kota metropolitan terbesar kedua setelah kota Jakarta dan merupakan ibu kota provinsi Jawa Timur. Surabaya memiliki luas sekitar 350,54 kilometer persegi dengan jumlah penduduknya yang hampir mencapai 3 juta jiwa (2018). Dari jumlah penduduknya yang banyak dan kawasannya yang

\footnotetext{
${ }^{1}$ Jurnal ini adalah bagian dari skrispi Reyhan Devtyan Muhamad, NIM: 041511433179 , yang diuji pada tanggal 18 Oktober 2019.
} 
Muhamad, et al/Jurnal Ekonomi Syariah Teori dan Terapan Vol. 6 No. 12 Desember 2019: 2485-2497;

ANALISIS PENGARUH FAKTOR HARGA, PENDAPATAN, KUALITAS DAN ATRIBUT PRODUK ISLAM TERHADAP PURCHASE INTENTION DI KEDAI KOPI BYCOFFEE SURABAYA

strategis, kota metropolitan ini mejadi pusat perekonomian di Jawa Timur, sehingga indsutri industri kopi berkembang pesat di kota ini.

Salah satu yang berkecimpung di industri kopi Surabaya adalah By Coffee. By Coffee adalah sebuah perusahaan berkonsep coffee shop asal malang yang menjual produk-produk minuman kopi yang berspeliasisi dalam minuman es kopi susu dan juga menawarkan konsep tempat yang cozy dan nyaman untuk menjadi tempat nongkrong anak muda. By Coffee sudah memiliki tidak kurang dari 4 cabang di kota Malang, dan memiliki 1 cabang di Surabaya. Kios By Coffee cabang Surabaya terletak di jalan Flores no. 10, yang mana merupakan lokasi yang terletak di pusat kota Surabaya dan juga dekat dengan salah satu kampus universitas tertua di Surabaya yaitu kampus B Universitas Airlangga. Dari lokasinya yang strategis, By Coffee berpeluang untuk menarik pasar yang besar dari kalangan mahasiswa sampai karyawan kantoran yang membutuhkan asupan kafein dalam menunjang aktifitasnya.

By Coffee memiliki keunikan yang jarang di miliki oleh coffee shop lainnya, yaitu menerapkan beberapa prinsipprinsip agama Islam di dalam kegiatan operasionalnya. Selain menjual produk yang halal, By Coffee memiliki campaign andalan yaitu "minum sambil duduk" yaitu anjuran bagi para pelanggannya untuk menikmati kopi pesanannya dengan meminumnya sambil duduk yang disampaikan oleh service staff yang bertugas saat menyapa pelanggan, yang mana hal ini merupakan salah satu Sunnah dari Nabi Muhammad Shallallahu 'alaihi wasallam dalam hal makan dan minum. Contoh lainnya adalah manajemen By Coffee mewajibkan para pegawainya untuk segera berhenti melayani pelanggan di saat adzan berkumandang dalam rangka menunaikan kewajiban sholat lima waktu. Di saat seperti itu, kios untuk sementara tutup terlebih dahulu, sedangkan pelanggannya di minta untuk menunggu sampai para service staff selesai sholat.

Suatu kegiatan konsumsi tidaklah terjadi dengan apa adanya, melainkan didorong oleh perilaku-perilaku dari konsumen. Di dalam perspektif konvensional dengan pemahaman kapitalis, kegiatan konsumsi itu ditujukan hanya sekedar untuk memberikan kepuasan. Kepuasan ditentukan secara subyektif, tiap-tiap orang memiliki caranya sendiri dalam mencapai kepuasan tersebut. Hanya berangkat dari keinginan untuk memperoleh manfaat materil sebanyak-banyaknya dengan biaya yang serendah-rendahnya tanpa memperhatikan aspek-aspek halal haram yang ditetapkan oleh agama.

Berbeda dengan perilaku konsumsi yang diatur oleh agam Islam. Konsumsi sendiri merupakan perintah dari Allah subhanahu wata'ala kepada manusia agar mampu menjalani perannya 
Muhamad, et al/Jurnal Ekonomi Syariah Teori dan Terapan Vol. 6 No. 12 Desember 2019: 2485-2497; ANALISIS PENGARUH FAKTOR HARGA, PENDAPATAN, KUALITAS DAN ATRIBUT PRODUK ISLAM TERHADAP PURCHASE INTENTION DI KEDAI KOPI BYCOFFEE SURABAYA

sebagai kahlifah dimuka bumi. Namun terdapat batasan-batasan yang ditetapkan dalam kegiatan konsumsi, yang mana batasan ini telah ditetapkan oleh Allah, diajarkan kepada manusia melalui sang pembawa risalah yaitu nabi Muhammad shallallahu 'alaihi wasallam. Yang mana secara garis besar, kegiatan konsumsi yang diajarkn Islam adalah yang membawakan manfaat bagi kehidupan manusia dimuka bumi dan juga membawa manfaat bagi kehidupan manusia di kehidupan akhirat yang kekal abadi.

Islam adalah agama yang sempurna. Tidaklah ada suatu aspek dalam kehidupan seorang manusia melainkan sudah ada aturannya di dalam Islam. Bagi seorang muslim, peranan keimanan menjadi tolak ukur penting karena keimanan memberikan cara pandang seorang muslim terhadap dunia yang menjadi landasannya dalam berperilaku di setiap aspek kehidupannya.. Seseorang yang mengaku beriman akan senantiasa memperhatikan segala tindak tanduknya di kehidupan dunia, tidak terkecuali dalam kegiatan konsumsi.

Dengan hadirnya By Coffee ditengah-tengah masyarakat Surabaya, dengan usahanya menerapkan prinsip syariah dan membumikan perilaku ekonomi Islam, sudah seharusnya hal ini merupakan daya tarik tersendiri bagi masyarakat surabaya yang mayoritas muslim. Namun hal ini belum terbukti secara konkrit apakah pelanggan yang datang dan menjadikan produk ByCoffee sebagai pilihannya itu dikarenakan prinsipprinsip syariah yang diterapkan ataukah hanya sekedar pemuasan nafsu untuk menunjang kebutuhan akan mengikuti tren ngopi di coffee shop yang sedang booming.

Penelitian ini berusaha untuk menganalisa bagaimana pengaruh dari faktor harga, pendapatan, kualitas dan atribut Islam yang di tawarkan By Coffee terhadap keptusuan konsumen Surabaya dalam memilih produk By Coffee Surabaya. Apakah atribut Islam yang ada merupakan salah satu faktor yang menentukan keputusan pembelian terhadap ByCoffee.

\section{LANDASAN TEORI DAN PENGEMBANGAN HIPOTESIS}

Perilaku

masyarakat membelanjakan sebagian dari pendapatan untuk membeli sesuatu disebut pengeluaran konsumsi. Konsumsi merupakan fungsi dari pendapatan siap pakai (disposable income). Dengan kata lain, fungsi konsumsi menunjukkan hubungan antara tingkat pengeluaran konsumsi dengan tingkat pendapatan yang siap dibelanjakan (Ambarwati, 2014)

Teori permintaan pada dasarnya merupakan perangkat analisis untuk melihat besaran jumlah barang atau jasa yang diminta serta perubahan permintaan akan suatu barang atau jasa berdasarkan hukum permintaan. Perubahan permintaan akan suatu brang 
Muhamad, et al/Jurnal Ekonomi Syariah Teori dan Terapan Vol. 6 No. 12 Desember 2019: 2485-2497;

ANALISIS PENGARUH FAKTOR HARGA, PENDAPATAN, KUALITAS DAN ATRIBUT PRODUK ISLAM TERHADAP PURCHASE INTENTION DI KEDAI KOPI BYCOFFEE SURABAYA

atau jasa tersebut akan dapat dilihat dari perubahan ada kurva permintaan. Maka analisis permintaan akan suatu barang atau jasa erat kaitannya dengan perilaku konsumen. Konsumen adalah mereka yang memiliki pendapatan dan menjadi pembeli barang dan jasa di pasar. Permintaan adalah jumlah dari suatu barang atau jasa yang mau dan mampu dibeli pada pelbagai kemungkinan harga selama jangka waktu tertentu dengan anggapan hal-hal lain tetap sama (cateris paribus). Permintaan turunan (derived demand) adalah permintaan akan faktor produksi yang tergantung pada permintaan akan barang atau jasa yang dihasilkan oleh faktor atau sumber daya tersebut. (Parahate, 2013)

Kurva permintaan adalah suatu grafik yang menunjukkan hubungan antara harga suatu barang atau jasa dan jumlah atas barang atau jasa yang diminta. Bentuk umum kurva permintaan turun dari kiri-atas ke kanan-bawah sebagaimana dapat dilihat pada gambar. Kurva permintaan dapat dibedakan menjadi dua macam yaitu kurva permintaan individu dan kurva permintaan pasar (agregat). Kurva permintaan individu merupakan kedudukan titik-titik yang menghubungkan berbagai harga suatu komoditas dan kuantitas komoditas yang dibeli oleh setiap individu. Kurva permintaan pasar agregat merupakan penjumlahan permintaan-permintaan individu atas suatu barang dan jasa dalam berbagai tingkat harga. (Parahate, 2013)

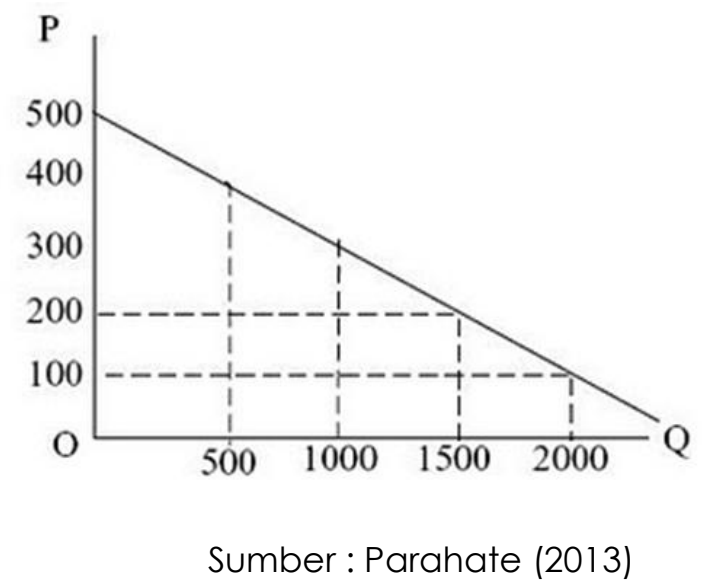

Gambar 1.

\section{Kurva Permintaan}

Hukum permintaan (The Law of Demand) adalah kuantitas barang yang diminta untuk suatu barang berhubungan terbalik dengan harga barang tersebut. Maka semakin rendah harga suatu barang atau jasa akan semakin tinggi tingkat permintaan akan barang atau jasa tersebut. Sebaliknya apabila harga atau jasa tersebut semakin tinggi, tingkat permintaan akan barang atau jasa tersebut akan semakin rendah. (Parahate, 2013)

Dalam teori konsumsi konvensional terdapat konsep Utility yaitu merupakan sebuah konsep yang abstrak tentang nilai guna dan manfaat atas barang dan jasa yang dikonsumsi. Sebuah konsep tentang cita rasa dan preferensi seseorang terhadap barang dan jasa untuk mendapatkan kepuasan. Utility akan didapatkan oleh seorang sepanjang barang dan jasa yang dikonsumsi sesuai dengan preferensi yang ada. Tingkat utility yang diterima konsumen atas barang dan 
Muhamad, et al/Jurnal Ekonomi Syariah Teori dan Terapan Vol. 6 No. 12 Desember 2019: 2485-2497;

ANALISIS PENGARUH FAKTOR HARGA, PENDAPATAN, KUALITAS DAN ATRIBUT PRODUK ISLAM TERHADAP PURCHASE INTENTION DI KEDAI KOPI BYCOFFEE SURABAYA

jasa yang berbeda, akan mengalami perbedaan. Namun sampai saat ini, utility tetap digunakan sebagai standar untuk mengukur nilai kepuasan. Misalnya, secangkir teh bernilai utility 10 , secangkir kopi nilainya 8 , secangkir susu 20, dan sebagainya.

Utility atau bisa disebut dalam ekonomi konvensional yaitu nilai guna merupakan kepuasan atau kenikmatan yang diperoleh seseorang dari mengkonsumsi barang-barang. Dalam membahas mengenai nilai guna perlu dibedakan diantara dua pengertian yaitu nilai guna dan nilai guna marjinal.

Sebagai umat beragama, terdapat korelasi antara kegiatan konsumsi dan religiusitas. Religiusitas adalah keterikatan individu secara penuh kepada Tuhan sebagai Sang Pencipta yang diinternalisasikan dalam diri individu dan dimanifestasikan dalam perilaku keseharian. Religius merupakan perilaku taat melaksanakan perintah Allah SWT dan konsisten menjadikan wahyu Allah SWT sebagai sumber inspirasi dalam pengembangan ilmu dan pelayanan.

Dalam Islam, konsumsi tidak dapat dipisahkan dari peranan keimanan. Peranan keimanan menjadi tolak ukur penting karena keimanan memberikan cara pandang dunia yang cenderung memengaruhi kepribadian manusia. Keimanan sangat memengaruhi kuantitas dan kualitas konsumsi, baik dalam bentuk kepuasan material maupun spiritual.
Konsumsi menurut perspektif Islam telah dijelaskan oleh para ulama. Menurut Al Ghazali konsumsi adalah (al hajjah) penggunaan barang atau jasa dalam upaya pemenuhan kebutuhan melalui berkeja (al iktisab) yang wajib dituntut berlandaskan etika syariat Islam dalam rangka menuju kemaslahatan menuju akhirat

prinsip ekonomi dalam Islam yang disyariatkan adalah agar tidak hidup bermewah-mewah, tidak berusaha pada pekerjaan yang dilarang, membayar zakat dan menjauhi riba, merupakan rangkuman dari akidah, akhlak dan syariat Islam yang menjadi rujukan dalam pengembangan sistem ekonomi Islam.

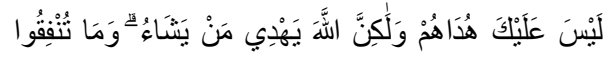

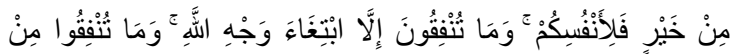

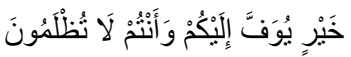

Laisa 'alaika hudāhum wa lākinnallāha yahdī may yasyā', wa mā tunfiqu min khairin fa li anfusikum, wa mā tunfiqụna illabtigā'a waj-hillāh, wa mā tunfiqu min khairiy yuwaffa ilaikum wa antum lā tuẓlamụn

Artinya : "Bukanlah kewajibanmu menjadikan mereka mendapat petunjuk, akan tetapi Allah-lah yang memberi petunjuk (memberi taufia) siapa yang dikehendaki-Nya. Dan apa saja harta yang baik yang kamu nafkahkan (di jalan allah), maka pahalanya itu untuk kamu sendiri. Dan janganlah kamu membelanjakan sesuatu melainkan karena mencari keridhaan Allah. Dan apa saja harta yang baik yang kamu nafkahkan, niscaya kamu akan diberi 
Muhamad, et al/Jurnal Ekonomi Syariah Teori dan Terapan Vol. 6 No. 12 Desember 2019: 2485-2497;

ANALISIS PENGARUH FAKTOR HARGA, PENDAPATAN, KUALITAS DAN ATRIBUT PRODUK ISLAM TERHADAP PURCHASE INTENTION DI KEDAI KOPI BYCOFFEE SURABAYA

pahalanya dengan cukup sedang kamu sedikitpun tidak akan dianiaya (dirugikan)." (QS. Al Baqarah : 272)

Dalam perilaku konsumen muslim bila digambarkan secara grafis dengan menggunakan alat analisis kurva indiferensi terhadap perilaku konsumen muslim perlu dilakukan suatu modifikasi dimana batasan yang membatasi konsumsi seorang konsumen muslim bukanlah hanya garis anggaran semata namun juga adanya batasan syariah. Sehingga batasan seorang konsumen muslim secara grafis dibatasi oleh garis anggaran dan syariat (budget and syariah line). Pada garis anggaran dan syariah ini secara posisi, letaknya berada lebih rendah dibandingkan pada garis anggaran. Karena adanya batasan dalam syariat Islam, seperti larangan untuk mengkonsumsi barang yang haram, larangan riba, larangan untuk konsumsi yang berlebihan dan kewajiban berzakat.

Menurut Harun (2016), Secara grafis hal ini dapat digambarkan sebagai berikut :

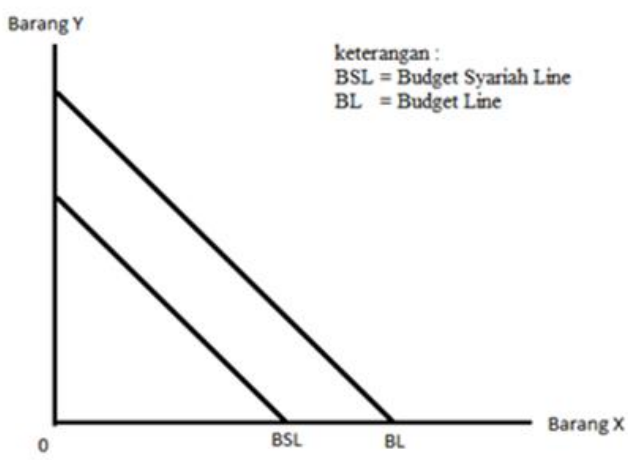

Sumber : Ekonomi Mikro Islam, Adiwarman Karim

\section{Gambar 2.}

\section{Kurva Indiferensi}

Selanjutnya tingkat kepuasan konsumen muslim optimum dapat tercapai pada persinggungan antara kurva indiferensi dengan garis anggaran dan syariah.

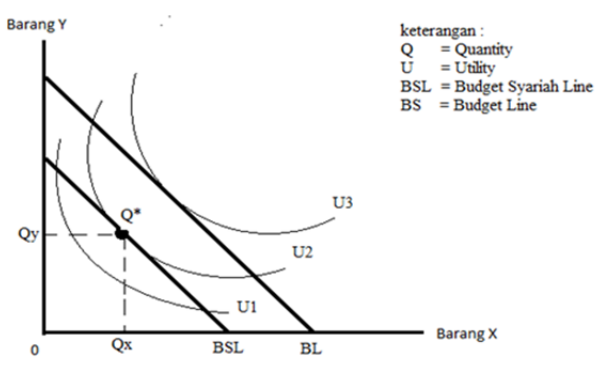

Sumber: Ekonomi Mikro Islam, Adiwarman Karim

\section{Gambar 3.}

\section{Titik Optimum Tingkat Kepuasan Muslim}

Di dalam buku berjudul "Ekonomi Mikro Islam" karya Adiwarman Karim dijelaskan bahwa berdasarkan gambar diatas tingkat kepuasan paling optimal dari konsumen seorang muslim adalah pada titik $Q^{*}$ yaitu pada kurva indiferensi $U_{2}$. karena pada titik inilah terjadi persinggungan antara kurva indiferensi dengan garis anggaran dan syariah. Pada kurva $U_{1}$, tingkat kepuasan konsumen belum optimum karena adanya pendapatan yang tidak dipergunakan untuk konsumsi, sehingga tingkat kepuasan konsumen yang iptimal belum tercapai. Sementara pada kurva $U_{3}$, merskipun kurva indiferensi lebih besar dibandingkan pada kurva $\mathrm{U}_{2}$ dan terjadi persinggungan dengan garis anggaran, namun tingkat kepuasan konsumen 
Muhamad, et al/Jurnal Ekonomi Syariah Teori dan Terapan Vol. 6 No. 12 Desember 2019: 2485-2497; ANALISIS PENGARUH FAKTOR HARGA, PENDAPATAN, KUALITAS DAN ATRIBUT PRODUK ISLAM TERHADAP PURCHASE INTENTION DI KEDAI KOPI BYCOFFEE SURABAYA

muslim tidaklah optimum dikarenakan adanya batasan syariah yang belum terpenuhi, seperti belum dikeluarkannya kewajiban zakat atau adanya barangbarang yang tidak boleh dikonsumsi, hal ini menyebabkan kurva $U_{3}$ tidak optimum bagi seorang muslim.

Keputusan pembelian ditentukan dengan konsumen membentuk pereferensi atas merek-merek yang ada di dalam kumpulan pilihan dan membentuk niat untuk membeli merek yang paling disukai. Merek yang paling disukai muncul setelah konsumen mengevaluasi dan mempertimbangkannya secara matang. Dua faktor yang mempengaruhi keputusan membeli dan tujuan membeli yaitu sikap orang lain dan faktor situasi yang tidak terprediksi. Pada tahap ini konsumen secara aktual membeli produk yang dipilih karena telah mantap pada keputusannya atas suatu produk. Setelah membeli produk, konsumen melakukan evaluasi atas keputusan dan tinndakannya dalam membeli. Konsumen akan mengalami level kepuasan atau ketidakpuasan tertentu.

\section{METODE PENELITIAN}

Pendekatan ini menggunakan alat analisis yang bersifat kuantitatif. Jenis variabel yang digunakan adalah variabel independen dan dependen. Variabel independen yang digunakan yaitu variabel harga, pendapatan, kualitas dan atribut Islam. Sedangkan variabel dependen adalah keputusan pembelian. Tujuan utama dari penelitian ini adalah untuk menganalisis pengaruh faktor harga, pendapatan, kualitas dan atribut agama Islam pada konsumen ByCoffee terhadap keputusan pembelian mereka.

\section{Definisi Operasional}

Definisi operasional dari variabel yang akan digunakan dalam penelitian ini adalah:

1. Harga, yaitu merupakan satu-satunya bauran pemasaran yang memberikan pemasukan atau pendapatan bagi perusahaan. Data primer diambil dengan kuisioner yang diisi oleh subyek penelitian dengan penilaianan skala likert.

2. Pendapatan merupakan suatu hasil yang diterima oleh seseorang atau rumah tangga dari berusaha atau bekerja. Data primer diambil dengan kuisioner yang diisi oleh subyek penelitian dengan penilaianan skala likert.

3. kualitas adalah hubungan antara produk dan pelayanan atau jasa yang diberikan kepada konsumen dapat memenuhi harapan dan kepuasan konsumen. Data primer diambil dengan kuisioner yang diisi oleh subyek penelitian dengan penilaianan skala likert.

4. Atribut produk Islam merupakan unsurunsur produk yang dipandang penting oleh konsumen dan dijadikan dasar pengambilan keputusan pembelian, atribut tersebut berupa atribut Islami. Data primer diambil dengan kuisioner 
Muhamad, et al/Jurnal Ekonomi Syariah Teori dan Terapan Vol. 6 No. 12 Desember 2019: 2485-2497; ANALISIS PENGARUH FAKTOR HARGA, PENDAPATAN, KUALITAS DAN ATRIBUT PRODUK ISLAM TERHADAP PURCHASE INTENTION DI KEDAI KOPI BYCOFFEE SURABAYA

yang diisi oleh subyek penelitian dengan penilaianan skala likert.

5. Keputusan pembelian adalah proses dimana konsumen secara aktual melakukan pembelian produk. Data primer diambil dengan kuisioner yang diisi oleh subyek penelitian dengan penilaianan skala likert.

\section{Penentuan Populasi dan Sampel}

Populasi dalam penelitian ini adalah pengunjung kedai kopi ByCoffee di wilayah Gubeng kota Surabaya. Dalam menentukan besarnya sampel, penelitian ini menggunakan cara penentuan sampel menurut Mustafa (2010) yaitu menggunakan Rumus Slovin.

\section{Slovin}

$n=\frac{N}{1+N e^{2}}$

Dimana:

$n=$ Jumlah sampel

$N=$ Jumlah populasi

$e=$ Tingkat kesaahan dalam memilih anggota sampel yang ditolerir sebesar $5 \%$

Jumlah populasi dalam penelitian ini adalah sebanyak 2100 pelanggan, sehingga presentase kelonggaran yang digunakan adalah $10 \%$ dan hasil perhitungan dapat dibulatkan untuk mencapai kesesuaian.

Berdasarkan rumus di atas, maka jumlah sampel yang digunakan dalam penelitian ini adalah sebagai berikut:

$n=\frac{2100}{1+2100 \times(0,1)^{2}}$
$n=95,45=96$ orang

Berdasarkan perhitungan di atas diketahui bahwa jumlah sampel pada penelitian ini adalah sebanyak 96 orang. Namun jumlah sampel yang diambil ditambah menjadi 120 agar sampel yang digunakan lebih baik dalam menginterpretasikan kesleuruhan populasi. Sampel yang diambil berdasarkan teknik probability sampling; simple random sampling. Pengambilan sampel ini dilakukan dengan teknik insindental.

\section{Jenis dan Sumber Data}

Dalam penelitian ini, data primer didapatkan dari hasil pengisian kuesioner oleh konsumen ByCoffee. Selain menggunakan data primer, penelitian ini juga menggunakan bantuan data sekunder, seperti mengambil informasi lain dari penelitian terdahulu, yang berhubungan dengan penelitian ini.

\section{Teknik Analisis}

Penelitian ini menggunakan Structural Equation Model (SEM) untuk mengukur hubungan antara harga, pendapatan, kualitas produk dan atribut agama Islam terhadap keputusan pembelian. Pengujian hipotesis pada penelitian ini dilakukan dengan menggunakan pendekatan structural Equation Model (SEM) berbasis Partial Least Square (PLS).

\section{Uji Validitas}

Prosedur pengujian validitas adalah convergent validity yaitu dengan mengkorelasikan skor item (component score) dengan construct validity score serta antar skor variabelnya dengn pengukuran discriminant validity. Indikator dianggap valid jika memiliki nilai AVE di 
Muhamad, et al/Jurnal Ekonomi Syariah Teori dan Terapan Vol. 6 No. 12 Desember 2019: 2485-2497; ANALISIS PENGARUH FAKTOR HARGA, PENDAPATAN, KUALITAS DAN ATRIBUT PRODUK ISLAM TERHADAP PURCHASE INTENTION DI KEDAI KOPI BYCOFFEE SURABAYA

atas 0,5 atau memperlihatkan seluruh outer loading dimensi variabel memiliki nilai loading $>0,5$ sehingga dapat disimpulkan bahwa pengukuran tersebut memenuhi kriteria validitas konvergen (Chin, 1995).

\section{Uji Reabilitas}

Uji realibilitas dapat diukur dengan menggunakan nilai Cronbach's Alpha dan composite reliability untuk mengukur tingkat realibilitas konsistensi pertanyaanpertanyaan dalam instrumen untuk mengukur sebuah konstruk. Namun menurut Salisbury et al. (2002), composite reliability lebih baik dalam mengestimasi konsistensi internal suatu konstruk. Jika nilai yang didapat pada Cornbach Alpha menunjukkan hasil lebih dari 0,7 maka konstruk tersebut dinyatakan reliabel (Nunnaly dan Bernstein, 1994). Sedangkan untuk composite reliability, nilai rule of thumb yang harus didapatkan untuk dinyatakan reliabel adalah 0,7 meskipun 0,6 juga masih dapat diterima (Hair et al., 2008).

\section{Uji Structural Model}

Structural/inner model dapat diukur dengan melihat nilai R-Square model yang menunjukan seberapa besar pengaruh antar variabel dalam model. Kemudian langkah selanjutnya adalah estimasi koefisien jalur yang merupakan nilai estimasi untuk hubungan jalur dalam model struktural yang diperoleh dengan prosedur bootstrapping dengan nilai yang dianggap signifikan jika nilai $\dagger$ statistik lebih besar dari 1,64 (significance level 5\%) untuk masing-masing hubungan jalurnya. Dari pernyataan di atas, maka dapat disimpulkan bahwa :

1. H1, H2, H3, dan H4 diterima jika signifikasi > 0,05. Maka, harga, pendapatan, kualitas dan atribut Islam memiliki pengaruh yang signifikan terhadap keputusan pembelian.

2. $\mathrm{H} 1, \mathrm{H} 2, \mathrm{H} 3$, dan $\mathrm{H} 4$ ditolak jika signifikasi > 0,05. Maka, Maka, harga, pendapatan, kualitas dan atribut Islam tidak memiliki pengaruh yang signifikan terhadap keputusan pembelian.

\section{HASIL DAN PEMBAHASAN}

\section{Hubungan Harga Terhadap Keputusan Pembelian}

Pada penelitian ini faktor harga tidak memiliki pengaruh yang signifikan karena banyak barang pengganti yang beredar dengan harga yang tidak jauh berbeda dengan harga yang ditetapkan di ByCoffee.

Penelitian ini sejalan dengan penelitian yang telah dilakukan oleh Yazia (2014) yang meneliti tentang pengaruh faktor harga terhadap keputusan pembelian pada produk ponsel BlackBerry dan penelitian yang dilakukan oleh Yenny Erica, Herry Hudrasyah (2017) mengenai faktor yang mempengaruhi keputusan untuk mengunjungi kembali Siete Café di kota Bandung ditemukan bahwa harga menjadi salah satu faktornya. 
Muhamad, et al/Jurnal Ekonomi Syariah Teori dan Terapan Vol. 6 No. 12 Desember 2019: 2485-2497; ANALISIS PENGARUH FAKTOR HARGA, PENDAPATAN, KUALITAS DAN ATRIBUT PRODUK ISLAM TERHADAP PURCHASE INTENTION DI KEDAI KOPI BYCOFFEE SURABAYA

Hubungan Pendapatan Terhadap

\section{Keputusan Pembelian}

Pendapatan

terhadap keputusan pembelian konsumen terhadap produk ByCoffee. Hasil penelitian menunjukkan hubungan antara pendapatan dengan permintaan rumah yaitu bahwa makin besar pendapatan yang diterima maka akan semakin meningkat pula intensitas konsumen untuk memilih ByCoffee sebagai kebutuhan untuk melepas dahaga atau hanya sekedar nongkrong yang merupakan gaya hidup dizaman sekarang ini. Dapat diketahui bahwa pendapatan berpengaruh positif terhadap keputusan pembelian.

Sehingga hasil penelitian ini sesuai dengan penelitian yang dilakukan Hardini dan Woyanti (2012) mengenai permintaan terhadap rumah sederhana yang terletak di Puri Indah Mas di kota Semarang yang mana dari sekian faktor yang diteliti salah satu faktor yang mempengaruhinya adalah pendapatan. Penelitian lainnya yang sejalan adalah penelitian yang dilakukan oleh Utami dan Hamid (2016).

\section{Hubungan Kualitas Terhadap Keputusan Pembelian}

Kualitas sangat mempengaruhi konsumen dalam mengambil keputusan pembelian dari perusahaan tertentu dan tercakup didalamnya kualitas Produk, pelayanan serta fasilitas tempat yang disediakan. Apabila kualitas ditingkatkan, perilaku konsumen untuk melakukan pembelian juga akan meningkat.
Hasil penelitian ini pun sejalan dengan penelitian yang dilakukan oleh Putra (2016) bahwa kualitas berpengaruh positif dan signifikan tehadap keputusan pembelian produk minuman bersoda merek Coca-cola. Penelitian ini memiliki kesamaan yaitu ukuran kualitas yang diukur adalh kualitas produk minuman, sehingga dapat disimpulkan bahwa pada produk minuman, kualitas merupakan suatu hal yang amat penting untuk dopertimbangkan dalam menentukan keputusan pembelian.

\section{Hubungan Atribut Islam Terhadap Keputusan Pembelian}

Hasil penelitian ini menunjukkan bahwa atribut Islam merupakan faktor yang memiliki pengaruh signifikan terhadap keputusan pembelian konsumen ByCoffee.

sesuai dengan penelitian yang telah diteliti oleh Tiara Khoerunnisa, Sunaryodan Astrid Puspaningrum (2016) tentang keputusan pembelian makanan halal. Keputusan pembelian untuk memilih makanan halal merupakan salah satu cerminan keimanan seseorang karena Allah subhanahuwata'ala yang memerintahkannya yang diabadikan didalam Al-Qur'an surat Al-Baqarah.

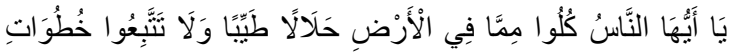

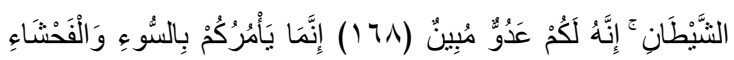

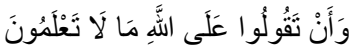

"Hai sekalian manusia, makanlah yang halal lagi baik dari apa yang terdapat di bumi, dan janganlah kamu mengikuti langkah-langkah syaitan; karena sesungguhnya syaitan itu adalah musuh 
Muhamad, et al/Jurnal Ekonomi Syariah Teori dan Terapan Vol. 6 No. 12 Desember 2019: 2485-2497; ANALISIS PENGARUH FAKTOR HARGA, PENDAPATAN, KUALITAS DAN ATRIBUT PRODUK ISLAM TERHADAP PURCHASE INTENTION DI KEDAI KOPI BYCOFFEE SURABAYA

yang nyata bagimu. Sesungguhnya syaitan itu hanya menyuruh kamu berbuat jahat dan keji, dan mengatakan terhadap Allâh apa yang tidak kamu ketahui". AlBaqarah/2:168-169).

Dan penelitian yang dilakukan oleh Mahesh Patel (2012) yang meneliti pengaruh religiusitas terhadap perilaku berbelanja dinegara India. Dari penelitian tersebut terdapat temuan bahwa perilaku belanja seseorang dibedakan berdasarkan religiusitas dari agama mereka masing-masing yang aberasal dari keimanan. Terdapat juga penelitian lain yang dilakukan oleh Siti, Ima dan Aan (2016) tentang pengaruh religiusitas terhadap etika konsumsi dari para siswa yang menuntut ilmu di pesantren Daarut Tauhid kota Bandung. Dijelaskan didalam penelitian tersebut bahwa religiusitas mempengaruhi etika konsumsi yang mana hal ini merupakan salah sau tolok ukur tingkat keimanan seseorang.

Semakin tinggi keimanan seseorang maka disetiap lini kehidupannya akan dipengaruhi oleh faktor religiusitas, dan pemahaman sebaliknya adalah semakin lemah iman seseorang maka semakian lemah faktor religiusitas dalam mempengaruhi tindak tanduknya selama hidup di dunia, termasuk dalam hal ini adalah kegiatan konsumsi untuk menjalani kehidupan di muka bumi ini.

\section{v. KESIMPULAN DAN SARAN}

\section{Kesimpulan}

Penelitian ini bertujuan untuk menganalisis pengaruh dari faktor harga, pendapatan, kualitas dan atribut Islam terhadap keputusan pembelian di ByCoffee Surabaya, dari hasil penelitian dapat disimpulkan bahwa:

1. Faktor harga tidak memiliki pengaruh yang signifikan karena banyak barang pengganti yang beredar dengan harga yang tidak jauh berbeda dengan harga yang ditetapkan di ByCoffee.

2. Hasil penelitian menunjukkan hubungan antara pendapatan dengan keputusan pembelian. Semakin besar pendapatan yang diperoleh individu mempunyai pengaruh positif terhadap keputusan untuk melakukan pembelian terhadap produk ByCoffee.

3. Kualitas sangat mempengaruhi konsumen dalam mengambil keputusan pembelian dari perusahaan tertentu dan tercakup didalamnya kualitas Produk, pelayanan serta fasilitas tempat yang disediakan. Apabila kualitas ditingkatkan, perilaku konsumen untuk melakukan pembelian juga akan meningkat

4. Hasil penelitian ini menunjukkan bahwa atribut Islam merupakan faktor yang memiliki pengaruh signifikan terhadap keputusan pembelian konsumen ByCoffee. Maka disimpulkan bahwa konsumsi yang dilakukan bukan sebatas pemenuhan jasmani, namun juga rohani. 
Muhamad, et al/Jurnal Ekonomi Syariah Teori dan Terapan Vol. 6 No. 12 Desember 2019: 2485-2497; ANALISIS PENGARUH FAKTOR HARGA, PENDAPATAN, KUALITAS DAN ATRIBUT PRODUK ISLAM TERHADAP PURCHASE INTENTION DI KEDAI KOPI BYCOFFEE SURABAYA

Saran

Dari hasil temuan penelitian ini, dapat diketahui bagaimana pengaruh faktor harga kurang berpengaruh signifikan terhadap keputusan pembelian karena banyaknya produk sejenis yang memiliki harga yang bersaing bahkan lebih murah, maka disarankan agar kembali meninjau ulang tentang harga yang di banderol agar harga tersebut berpengaruh positif terhadap keputusan pembelian.

Hasil temuan menemukan bahwa atribut produk Islam memiliki pengaruh yang signifikan, maka hendaknya faktor ini senantiasanya dipelihara bahkan ditingkatkan dan senantiasa disertai dengan niat yang ikhlas agar menjadi ladang amal kebaikan yang mana konsumen mendapatkan manfaat yang baik dari atribut ini.

Selain itu diharapkan penelitian ini dapat menjadi informasi dan bahan pertimbangan bagi para pelaku bisnis untuk emmperhatikan faktor-faktor yang berpengaruh signifikan terhadap keputusan pembelian. Diharapkan pula untuk pelaku bisnis lain dapat menerapkan atribut agama Islam di produknya karena terbukti atribut tersebut beroengaruh signifikan terhadap keputusan pembelian.

Untuk pengembangan keilmuan, diharapkan penelitian ini dapat memberikan sumbangan bagi khazanah ilmu pengetahuan, khususnya dalam bidang ekonomi Islam dengan menggambarkan pelaku bisnis yang mencoba membumikan perekonomian Islami ditengah-tengah masyarakat dan hal tersebut memiliki pengaruh yang positif secara materil dan tentunya secara rohani. Terakhir, bagi peneliti selanjutnya diharapkan penelitian ini dapat digunakan sebagai acuan atau bahan referensi bagi penelitian selanjutnya disamping itu, tanpa mengubah tema dari penelitian ini, disarankan agar penelitian selanjutnya dapat lebih komperhensif dalam menganalisis faktor atribut Islam karena masih sedikitnya penelitian yang membahas hal ini.

\section{DAFTAR PUSTAKA}

Mustafa, Z. E. (2009). Mengurai Variabel hingga Intrumentasi. Yogyakarta: Graha ilmu.

Ambarwati, N. (2014). Analisis Kausalitas Antara Konsumsi Rumah Tangga Dengan PDRB Perkapita Di Jawa Tengah Periode Tahun 19862011 (Doctoral dissertation, Universitas Muhammadiyah Surakarta).

Hair et al., (1998). Multivariate Data Analysis. Fifth Edition. Prentice Hall, Upper Saddle River : New Jersey.

Harun, H. (2016). Analisis Penurunan Harga BBM Terhadap Kemampuan Konsumsi Kebutuhan Primer Masyarakat Dusun Glatik Desa Watesnegoro Mojokerto (Perspektif Teori Konsumsi Islam) (Doctoral dissertation, UIN Sunan Ampel) 
Muhamad, et al/Jurnal Ekonomi Syariah Teori dan Terapan Vol. 6 No. 12 Desember 2019: 2485-2497;

ANALISIS PENGARUH FAKTOR HARGA, PENDAPATAN, KUALITAS DAN ATRIBUT PRODUK ISLAM TERHADAP PURCHASE INTENTION DI KEDAI KOPI BYCOFFEE SURABAYA

Khoerunnisa, T., \& Puspaningrum, A. (2016). Pengaruh Kepercayaan Agama, Logo Halal, Pemaparan, dan Alasan Kesehatan terhadap Kesadaran Merek dan Keputusan Pembelian Makanan Halal pada Penduduk Kota Malang. Ekonomi Bisnis, 21 (1), 36-45.

Parahate, F. X. (2013). Analisis Permintaan dan Efisiensi Energi Listrik di Indonesia tahun 1990-2010. (Jurnal IImu Ekonomi, Universitas Atma Jaya Yogyakarta).

Yazia, V. (2014). Pengaruh Kualitas Produk, Harga Dan Iklan Terhadap Keputusan Pembelian Handphone Blackberry. Journal of Economic and Economic Education, 2(2), 165-173.

Patel, M. (2012). Influence of religion on shopping behaviour of consumersan exploratory study. Abhinav
National Monthly Refereed Journal of Research in Commerce \&Management, 1 (5), 68-78.

Putra, Y. U. V. (2014). Analisis faktor-faktor perilaku konsumen pengunjung coffee shop di Malang: Studi kasus pengunjung coffee shop di Kecamatan Lowokwaru dan Klojen Kota Malang (Doctoral dissertation, Universitas Islam Negeri Maulana Malik (brahim).

Qudsiyah, S., Amaliah, I., \& Julia, A. (2016). The Influence of Religiosity Values on the Consumption Ethics of the Student of Islamic Boarding School of Daarut Tauhiid Bandung.

Utami, A. B., Hamid, F. Z., \& Onida, M. (2016). Pengaruh Harga, Pendapatan dan Lokasi Terhadap Keputusan Pembelian Rumah Di D'kranji Residence Tahap || Bekasi Barat. Epigram, $12(2)$. 